原著論文

\title{
有限要素法を用いたシューズのグリップ性評価手法
}

\author{
高 本 義 国* 西 脇 剛 史*
}

\section{An Estimation Method of Shoe Sole Traction based on FEM}

\author{
Yoshikuni TAKAMOTO* and Tsuyoshi NISHIWAKI*
}

\begin{abstract}
Shoe traction has a great influence on running performance. Materials used in shoe soles have visco-elastic properties with strain-rate dependency. In previous studies concerning shoe traction, "Coloumb's friction theory" of contact between two rigid bodies has been used, however, this application has not been proper. In this study, the assumption that the appearance of slipping depends upon the stored energy in the sole/surface interface is proposed. The numerical estimation method of shoe traction, based on FEM considering the visco-elastic properties of shoes materials, is developed. The appropriateness of the numerical model is discussed by comparing experimental results. Using this model, the effects on traction of the constitutional parameters, midsole hardness, and outersole density are quantified. Furthermore, the application of the model to traction on wet surface is discussed.
\end{abstract}

Key words : Finite Element Method, Shoe Sole Traction, Visco-Elastic Property, Grip Index, Wet Grip Index

\section{1. 緒言}

シューズと路面との間の滑りは，ランニング 動作に大きな影響を及ぼす。ランニングシュー ズにおいても，グリップ性は安全面や機能面に おける最も重要なシューズ機能の一つとされて おり，グリップ性を高めるためのシューズソー ルの研究開発は盛んに行われている.

ランニングシューズには，グリップ性以外に も重量, 耐久性, 衝撃緩衝性, 屈曲性など様及 な要求特性が存在する. そのため, 通常ランニ
ングシューズソールはミッドソールとアウター ソールと呼ばれる二つのパーツを積層すること によって形成される。ミッドソールに使用する 材料としては，エチレンビニルアセテート発泡 体 (以下, EVA と称する), アウターソールに 使用する材料としてはラバー，ラバーを発泡さ せたラバースポンジ (以下， RS と称する) など が主流を占めている。

従来のシューズグリップ性に関する研究は, クーロン摩擦理論に基づくアウターソールと路 面との間の界面特性の向上を目的とした表面改

†原稿受付 1998年 3 月 3 日

1997年10月スポーツ工学シンポジウム1997にて発表

*株式会社アシックススポーツ工学研究所

干651-2271 兵庫県神戸市西区高塚台 6-2-1

*ASICS Corporation, 6-2-1, Takatsukadai, Nishi, Kobe, Hyogo, Japan (651-2271) 
質が中心であった ${ }^{122)}$. しかしながら，クーロン 摩擦理論は，変形を考慮しない剛体間の摩擦を 想定しており，非線形性，ひずみ速度依存性を 有する粘弾性材料である EVA やラバースポンジ から構成されるシューズのグリップ性評価にそ れを適用することは妥当ではない。

本研究を遂行する上で，滑りのメカニズムと して式(1)に示す仮説を提唱する。

$$
\mathrm{SEI}=\mathrm{TE}-\mathrm{SES}
$$

ここで, SEI (Strain Energy in sole/surface Interfase）はソール路面間の凝着相に蓄積され るエネルギー, TE (Total Energy) はランニン グ動作を介してソールに加えられるエネルギー, SES（Strain Energy in Sole）はソールに蓄積 されるエネルギーを示す。

滑りは，ソールと路面間の凝着相に一定のせ ん断エネルギーが蓄稓され，その相が破壊され ることにより発生するという仮説を提案した。 ランニング中，ソールにはその種類に関わらず 一定量の外力が加わるが，その一部はソールの 変形としてソール内部に蓄積され, 残りは凝着 相を破壊するエネルギーとなる。この仮説によ れば，高いグリップ性を有するソールとは，TE
を可能なかぎり SES に充当し, SEI を低減させ るソールであると考之られる。

本研究では，まず，上記仮説に基づき，シュ 一ズソール材料の粘弾性特性を考慮した数值モ デルによるシューズグリップ性評価手法を開発 し，実験との比較検討からその妥当性を議論す る. 次に, 材料・形状等のソール構成要素が, グリップ性に与える影響を検討し，さらに，需 れた路面上でのグリップ性評価手法を提案する。 最後に，本研究によって得られた知見を基に， 高グリップ性を有するソールの設計指針を示す。

\section{2. 解 析 手 法}

グリップ性が問題となるシューズソール前足 部の一部分 $(100 \times 20 \times 20 \mathrm{~mm})$ を，グリップ性数 值評価モデルとした。ソールはミッドソールと アウターソールの二層構造をなし，ともに立体 要素でモデル化した（Fig.1）.

ミッドソールにはシューズ材料として一般的 に使用される EVA，アウターソールには RS を 使用した，EVA 硬度，RS 密度等は，実際のシ ユーズに使用される範囲内から選択した。

EVA，RSの準静的一軸圧縮試験及び落錐衝
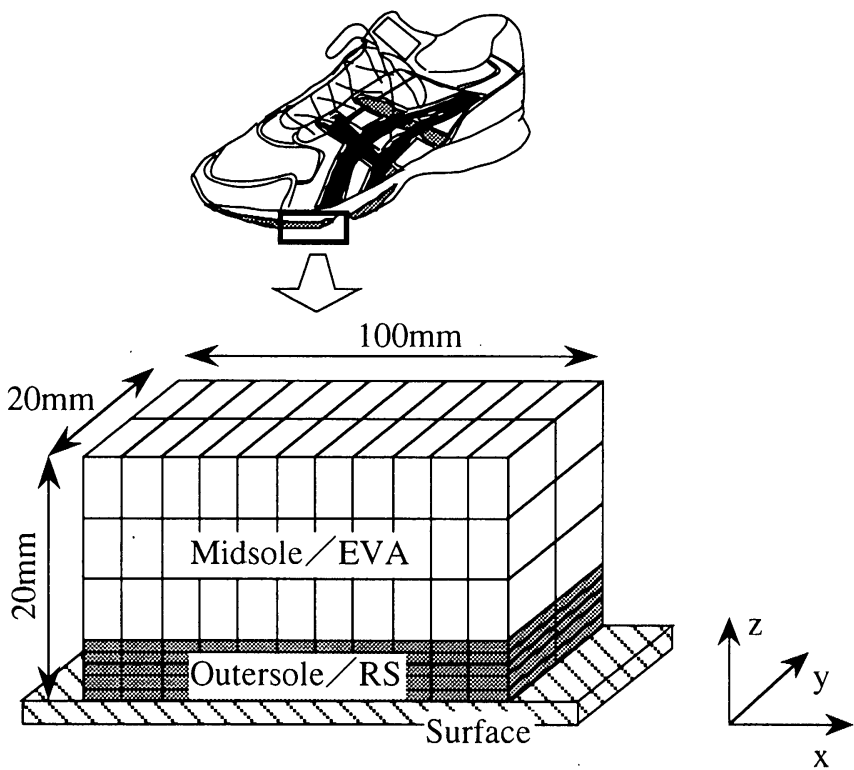

Fig.1 The numerical model using in this study 


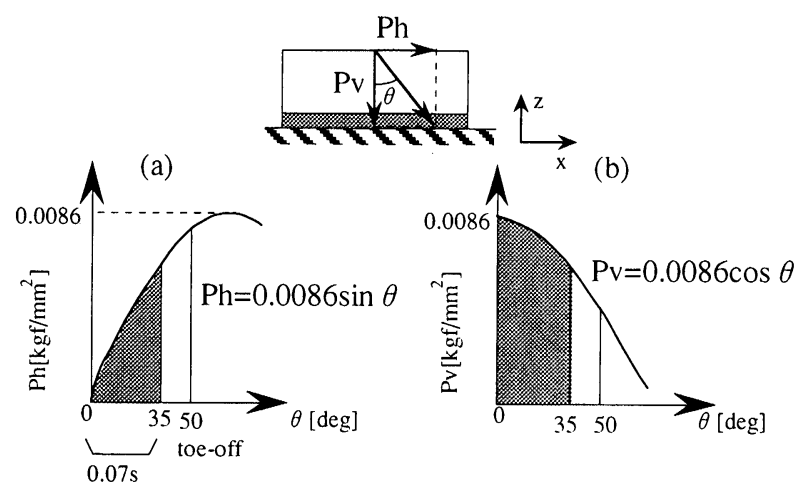

Fig.2 Loads acted on shoes during contact phase

(a) horizontal loads, (b) vertical loads

突実験を行い，前者より得られた応力ーひずみ

関係を，後者より得られた落錐の加速度応答及 び材料の変位を再現できる解析モデルを, 各々 の材料について構築しだ).

ランニング中にソールに作用する荷重の測定 には，地面反力測定装置（サンプリング周波数 $1000 \mathrm{~Hz}$ ，Kisler 社製）を用いた．被検者は体重 $50 \mathrm{kgf}$ の女性ランナー一名である.被検者の体重 によりソールに加わる荷重の絶対値は異なるも のの, 時系列変化の態様は被検者間において差 はなく，ソールのグリップ性の相対評価に対し て，ランナーの体重の大小は影響を及ぼさない と考え, 被験者は標準的な体重を有するランナ 一一名とした。測定された荷重を，接触面積で 除することにより，解析モデルに作用させる単 位面積あたりの水平荷重 $\mathrm{Ph}$ 及び鉛直荷重 $\mathrm{PV}$ を 求めた (Fig.2).

単位面積当りの水平荷重 $\mathrm{Ph}$, 及び鉛直荷重 Pvは，それぞれ式(2)，(3)で与えられる。ここで, $\theta$ は荷重と鉛直軸とのなす角度であり, 荷重作用 時間 $\mathrm{t}$ との間には式(4)の関係が成り立つ. $\mathrm{t}=0$ は, ランニング着地中期, 水平荷重が制動期か ら推進期に変わる時点に相当する．鉛直荷重は この時点において最大となり, 離地に向かって 余弦的に減少する。これに対して，水平荷重は この時点において0となり,離地に向かって正弦 的に増加する.

$$
\begin{aligned}
& \mathrm{Ph}=0.0086 \sin \theta \\
& \mathrm{Pv}=0.0086 \cos \theta \\
& \theta=500 \mathrm{t}
\end{aligned}
$$

先の仮説に基づき，グリップ性を定量化する 指標として,グリップ性数值評価指標 Grip Index (以下，GI と称する) と定義した. GI は，式(5) のようにミッドソールとアウターソールを合わ せたソール全体に蓄積されるエネルギーを，ア ウターソール単位体積当たりに蓄積されるエネ ルギーで除することにより求める.

$$
\mathrm{GI}=\mathrm{E}_{\text {tot }} / \mathrm{E}_{\text {out }}^{\prime}=\left(\mathrm{E}_{\text {out }}+\mathrm{E}_{\mathrm{mid}}\right) / \mathrm{E}_{\text {out }}^{\prime}
$$
ここで, $\mathrm{E}_{\mathrm{tot}}=\mathrm{E}_{\mathrm{out}}+\mathrm{E}_{\mathrm{mld}}$ はミッドソールとアウ ターソールを合わせたソール全体に蓄積される エネルギー， $\mathrm{E}_{\text {out }}$ はアウターソール単位体積当 たりに蓄積されるエネルギーを示す。前者は式 (1)における SES, 後者は SEIに対応する. GI が 大きくなるほど,グリップ性が高いことになる。

高速度ビデオ（毎秒500コマ，NAC 社製）を 用いて，ソールと路面との間の滑りを観察した 結果, 荷重作用開始から0.07秒経過時において, 滑りが発生することが明らかとなった。そこで, 本解析では，この時点までに EVA 及び RSに蓄 積されたエネルギーから算出された GI を評価対 象とした。

\section{3. 解 析 結 果}

用いた解析対象は, Fig.3に示すような材料, 

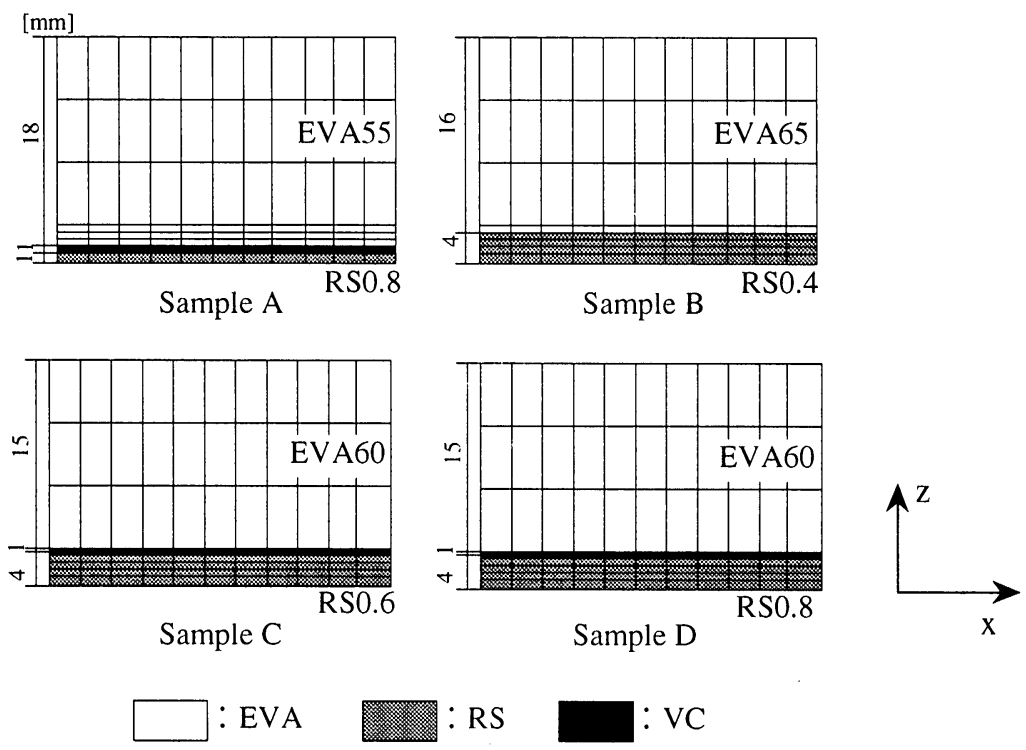

Fig.3 Sample variations
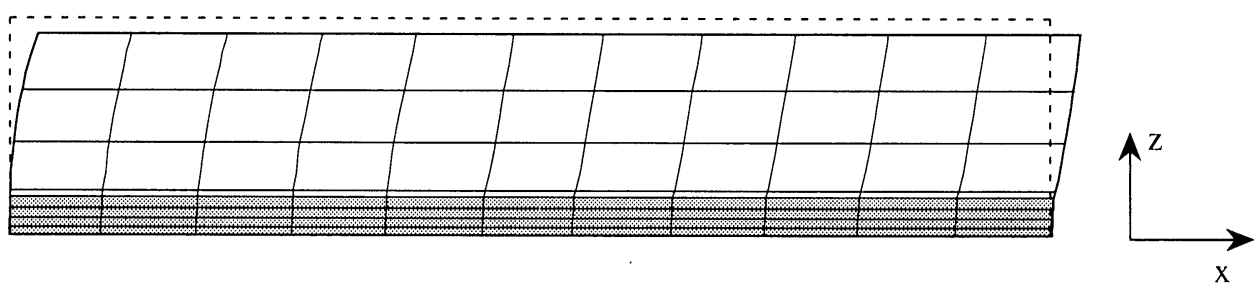

Fig.4 Side view of deformed sole shape (Sample B)

形状等のソール構成要素が異なる $\mathrm{A}-\mathrm{D} の 4$ 種 類のサンプルである.なお, $\mathrm{VC}$ は塩化ビニルシ ート（厚さ $1 \mathrm{~mm}$ ）を表すが, これはミッドソー ルの変形をアウターソールに伝達させないこと を目的に使用した，VCの弾性率は，EVA， RS のそれよりも極端に大きく，剛体板とみなすこ とができる.Fig.3中のEVA, RSに追記された 数值は, それぞれ EVA 硬度, RS 密度を示す. 硬度65の EVA と, 密度 $0.4 \mathrm{~g} / \mathrm{cm}^{3}$ の RS は, ほぼ 同程度の初期弾性率を示す。

Fig.4に, 解析結果の一例として, Fig.3サンプ ルBの変形状態を示す.

Fig.5に, サンプルA-Dの GI を示す. EVA 硬度 $55, \mathrm{RS}$ 密度 $0.8 \mathrm{~g} / \mathrm{cm}^{3}$ で, VC を挿入したサン プルAが, 最大の GI を有し, EVA 硬度 $65, \mathrm{RS}$

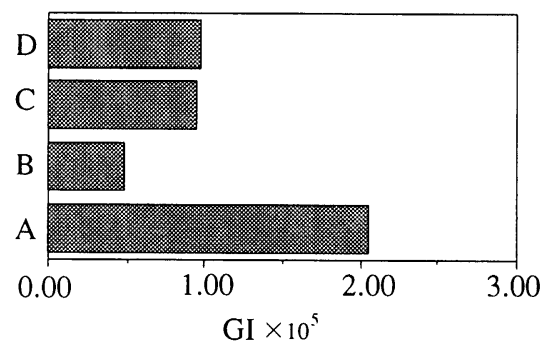

Fig.5 Numerical results, GI

密度 $0.4 \mathrm{~g} / \mathrm{cm}^{3}$ のサンプル Bが, 最小の GI を有す るという結果であった。

$$
\text { 4. 考察 }
$$

4. 1 GI の妥当性検証 

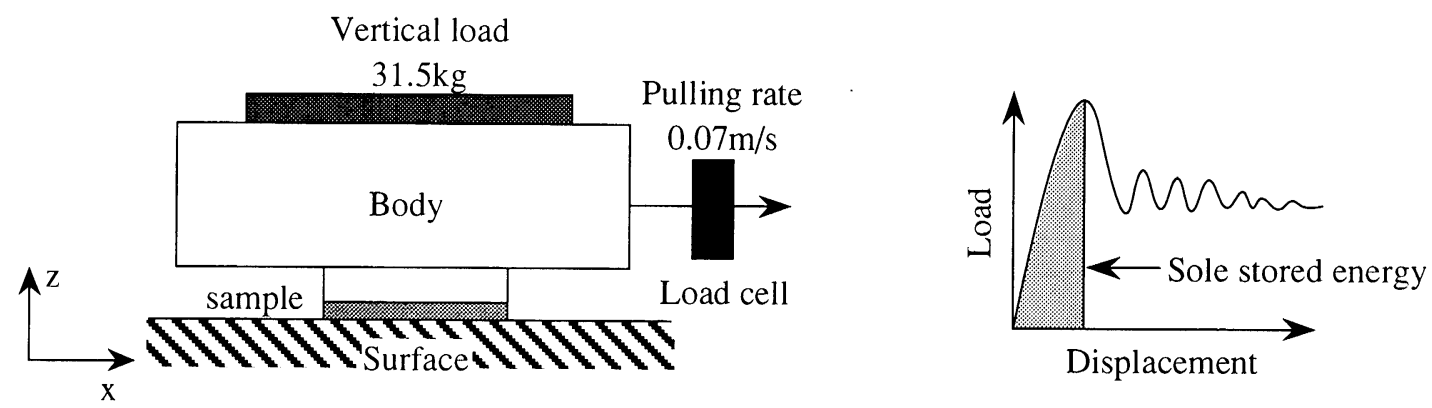

Fig.6 Experimental setup

GIによる数值評価手法の妥当性を検証するた めに，A-D4種類のサンプルを作製し，滑り試 験を用いたグリップ性測定を行った。本測定方 法は，Fig.6(a)に示すように，路面との間にソー ルサンプルを装着した台車に鉛直荷重 $31.5 \mathrm{kgf}$ を 作用させ, それを水平方向に引張速度 $0.07 \mathrm{~m} / \mathrm{s}$ で 金属製ワイヤ一を介して牽引し，ワイヤーに作 用する張力をロードセルにより測定するもので ある。

測定結果例を Fig.6(b)に示す. 滑りが発生する までの静止摩擦領域において, 得られた張力を 時間積分し，ソールに蓄積されるエネルギーを 算出した (Fig.6(b)中, 網かけ部). 静止摩擦領域 において，ソールに蓄積されるエネルギーが大 きいほど，グリップ性が高いことになる.

Fig.7に, GI と滑り試験結果の相関を示す.Fig. 7によれば, GIにより最もグリップ性が高いと評 価されたサンプルAは, 滑り試験においても最 もソールに蓄積されるエネルギーが大きかった。 GI と滑り試験結果との間には, $5 \%$ 水準で相関関 係があり, 本研究冒頭で提案した GIによる評価 が妥当であることが検証された。

\section{2 ソール構成要素がグリップ性に与える 影響}

GIによる数值評価手法を用いて,ソール構成 要素である EVA 硬度, RS 密度, 高剛性を有す るVCの挿入が, GIに与える影響を検討した。

Fig.8(a)一(c)には, (a) EVA 硬度, (b) RS 密度, (c) $\mathrm{VC}$ 挿入位置を変化させた時の, 式(5)中, GI, $\mathrm{E}_{\mathrm{tot}}$,

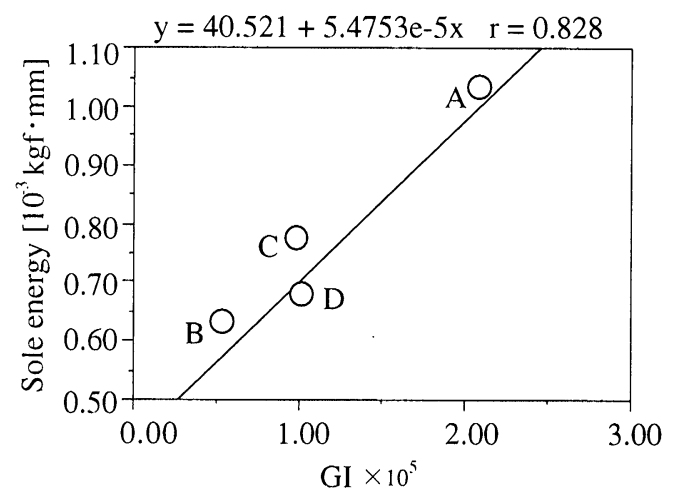

Fig.7 Relationship between GI and experimental results

$\mathrm{E}_{\text {out }}^{\text {ou示す。 }}$

まず, EVA 硬度の影響を検討するため, Fig. 3中モデルBを用いて, RS 密度を $0.6 \mathrm{~g} / \mathrm{cm}^{3}$ 一定と し, EVA 硬度を $55,60,65$ と変化させた時の GI を算出した.Fig.8(a)によると, EVA 硬度が小さ くなるほど GI は増加した。これは, EVA 硬度 が小さくなると,ソールの弾性率は小さくなり, $\mathrm{E}_{\mathrm{tot}}, \mathrm{E}_{\text {out }}$ はともに増加したが, 前者の増加率の 方が大きかったためである，以上より，ミッド ソールの変形を促すことにより，ソールに高い グリップ性を付与することができるといえる. 次に, RS 密度の影響を検討するため, Fig.3中 サンプルBを用いて EVA 硬度を60一定とし, RS 密度を0.4,0.6,0.8g/ $\mathrm{cm}^{3}$ と変化させた時の $\mathrm{GI}$ を 算出した. Fig.8(b)によると, RS 密度が大きくな るほど $\mathrm{GI}$ は増加した。これは， RS 密度が大き 
(a) EVA hardness

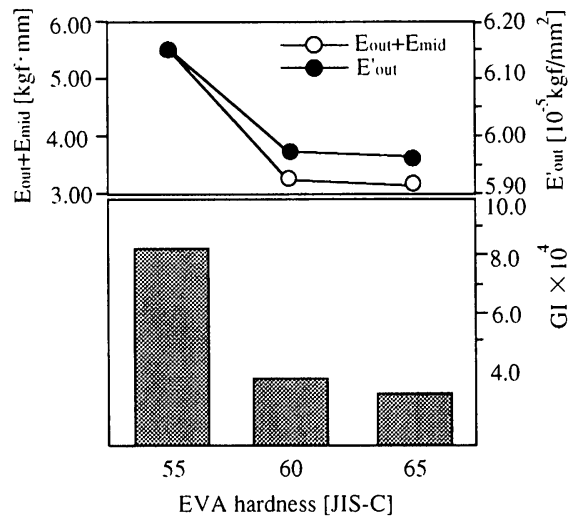

(b) RS density

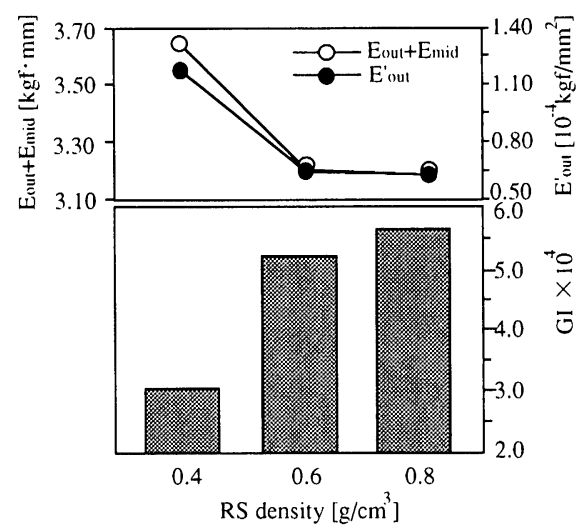

(c) VC inserted position

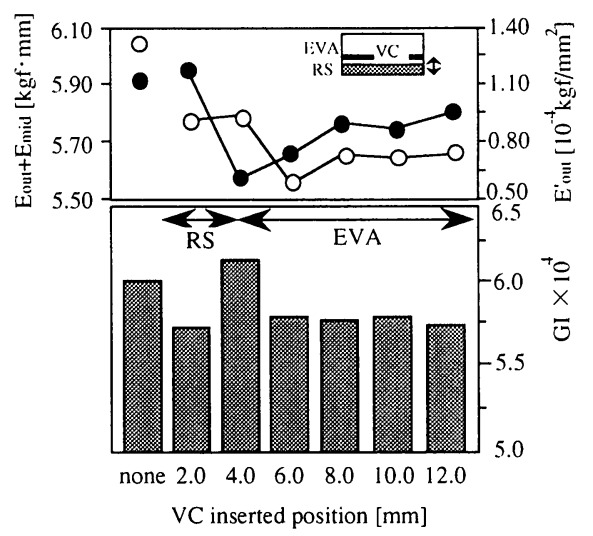

Fig.8 Effects of each shoes parameters on GI

くなると, $\mathrm{E}_{\mathrm{tot}}, \mathrm{E}_{\text {out }}^{\text {out }}$ はもに減少したが, 後者 の減少率の方が大きかったためである，以上よ ク，アウターソールの変形を抑制することによ ク，ソールに高いグリップ性を付与することが できるといえる。

前述したように，路面と接触しないミッドソ 一ルの変形を促し, 路面と接触するアウターソ 一ルの変形を抑制させることにより，ソールに 高いグリップ性を付与することが可能となる. しかしながら，剛性の大きく異なる両層を単純 に稓層した場合は，剛性の低い層が剛性の高い 首の変形に追随し，上記効果が十分に得られな い.そこで，上記効果を得るために，両層より も高剛性を有する第三層 (VC) を介在させるこ
とにより，両層間の変形の連続性を遮断する方 法を検討した. VCを介在させた場合の GI に与 える影響を検討するため, Fig.3サンプルDを用 いて EVA 硬度を $60, \mathrm{RS}$ 密度を $0.6 \mathrm{~g} / \mathrm{cm}^{3}$ 一定と し, VC 挿入位置をモデル最下層から $2.0,4.0$, $6.0,8.0,10.0,12.0 \mathrm{~mm}$ と変化させた時の GI を 算出した．Fig.8(c)によると，VCをミッドソー ルとアウターソールとの境界面に挿入した場合, $\mathrm{E}_{\mathrm{tot}}, \mathrm{E}_{\text {out }}$ はともに減少したが, 後者の減少率の 方が大きくなったため, 挿入無しの場合に比べ, GI は増加した. 一方, ミッドソール内部もしく はアウターソール内部に VC を挿入した場合は, 抻入無しに比べ, GI は小さくなった. 以上より, せん断変形量が大きく変化するミッドソールと 
アウターソールとの境界面に高剛性層を挿入す ることにより,両層間の変形の連続性を遮断し, ソールに高いグリップ性を付与することができ るといえる。

\section{3 ウェットな路面上でのグリップ性数值 評価}

上記解析モデルを応用し，ウェット状態にお けるグリップ性評価を検討した。ウェットな路 面上での滑りは, ソールと路面との間の水膜層 に一定のせん断エネルギーが蓄積され, それが 破壊することにより発生する。高速度ビデオ(毎 秒500コマ，NAC 社製）を用いて実際の滑りの 様子を観察すると，ドライな路面上ではソール が一定量変形した後, 滑りが発生するのに対し, ウェットな路面上ではソールの変形が生じる前 に, 水膜層が破壊し, 滑りが発生していること が確認できた。これは，ウェットな路面でのグ リップ性評価において, ソールと水膜層を独立 してモデル化する必要があることを示唆するも のである。そこで, 水膜層を線形はり要素で, ソールを立体要素で構成した複合モデルを，ウ エットな路面上でのグリップ性数值評価モデル として構築した. 各はり要素の長さは $1 \mathrm{~mm}$, 断面
積はその位置により変化させ, 断面積の総和が モデルの面積に等しくなるよう設定した4). 弾性 率はEVAおよびRSの初期弾性率（EVA0.5〜 $\left.0.8 \mathrm{kgf} / \mathrm{mm}^{2}, \mathrm{RS} 1.0 \sim 2.0 \mathrm{kgf} / \mathrm{mm}^{2}\right)$ に比べて小さ くなるように0.1kgf/ $/ \mathrm{mm}^{2}$ とた（Fig.9, 10).

式(6)のように, 水膜層に相当するはり要素部 分単位体積当りに蓄積されるエネルギーをWGI と定義し, WGI の大きさと水膜層の破壊しやす さに相関があると考え，それをウエットな路面 上でのグリップ性数值評価指標とした。

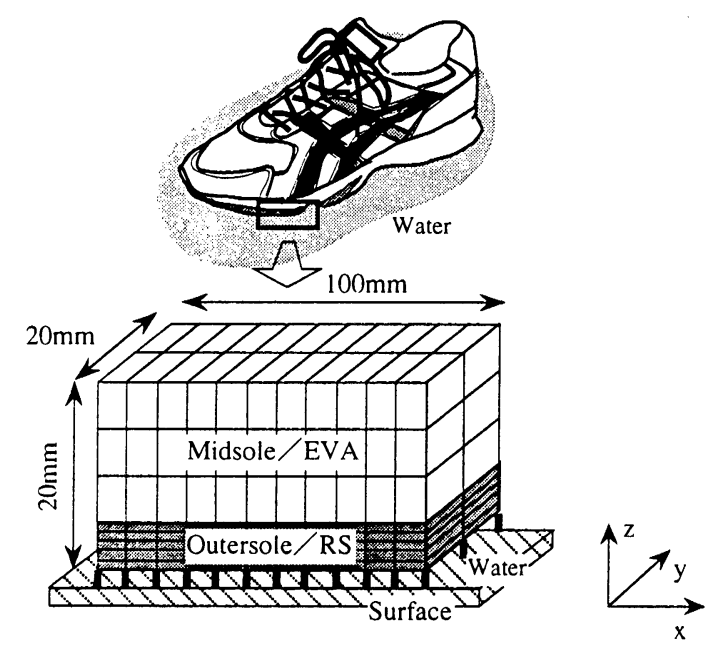

Fig.9 The numerical model on wet surface

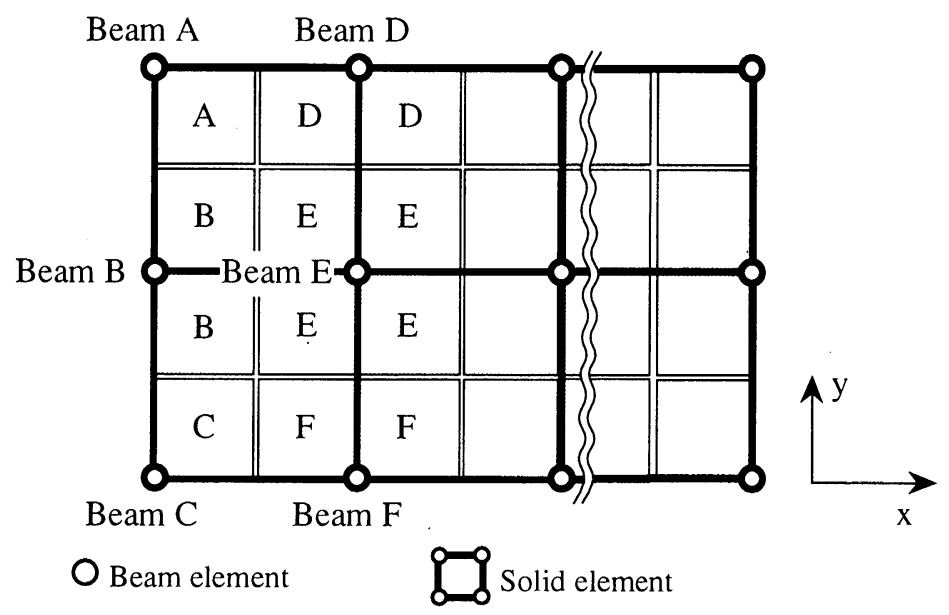

Sectional area of beam element

Fig.10 Top view of the model on wet surface including 176 solid elements and 36 beam elements, corresponded to sole and water, respectively 


$$
\mathrm{WGI}=1 / \mathrm{E}_{\mathrm{wat}}
$$

ここで, $\mathrm{E}_{\mathrm{wat}}$ は水膜部分単位体積当りに蓄積さ れるエネルギーを示す。

Fig.3に示した 4 種類のサンプルについて, WGI の算出を行った. Fig.8に得られた各 WGI を示す. Fig.11によれば, サンプルDが最大の WGI を有 し, サンプルBが最小の WGI を有した.この結 果から, GI とWGI との間には相関関係がない ことが確認できた.

WGI の妥当性を検証するために, 上記の 4 種 類のサンプルについて, 濡れた路面において, 同様のグリップ性測定を行った. Fig.12によれば, WGIにより最もグリップ性が高いと評価された サンプルDは, 滑り試験においても最大のグリ ップ性を有した. WGI と滑り試験結果との間に は, $5 \%$ 水準で相関関係があり, WGI がウェット な路面上でのグリップ性指標となることが検証 された。

\section{4 高グリップ性を有するソールの設計指 針}

上記結果により，ドライな路面においては， ミッドソールの変形を促進し，アウターソール の変形を抑制すると共に, せん断変形量が大き く変化する境界面に, 高剛性を有する第三層を 介在させることが, 高いグリップ性を得るため のソール設計の基本指針であることを示した. しかしながら, ウェットな路面においては, ド ライな路面と高グリップを有するソール構造が 異なる.これは, 各々の路面状態の特性を把握 し, 適切な解析モデルを選択する必要があるこ とを示している.

実用的なソール設計を行なう際，デザイン的 に, アウターソールの分割により形成される意 匠は不可欠である。足部からソールに作用する 荷重を, 感圧導電インクを用いた足圧分布測定 装置 (サンプリング周波数 $60 \mathrm{~Hz}$ ，テックスキャ ン社製）により，シューズソールと足裏との間 に発生する荷重の直接測定すると, 鉛直荷重最 大時において, Fig.13のような分布が得られた. この荷重分布は, 足の解剖学的特徵やランニン

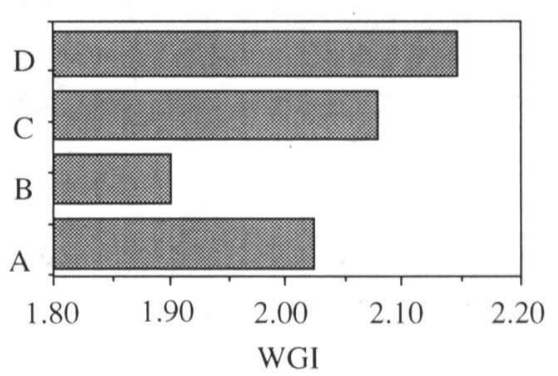

Fig.11 Numerical results, WGI on wet surface

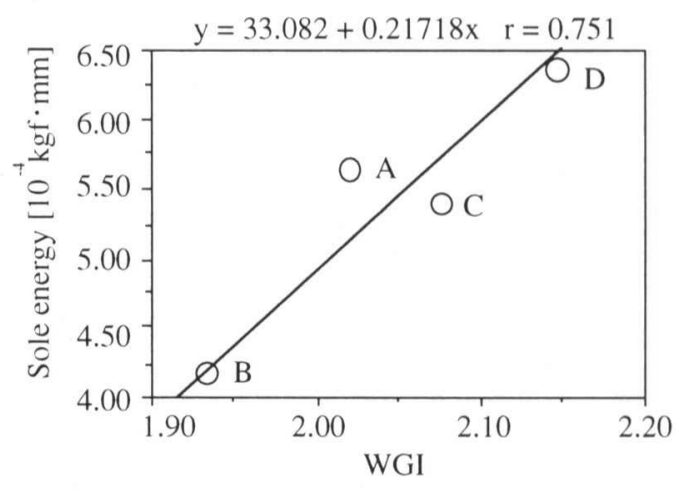

Fig.12 Relationship between WGI and experimental results on wet surface

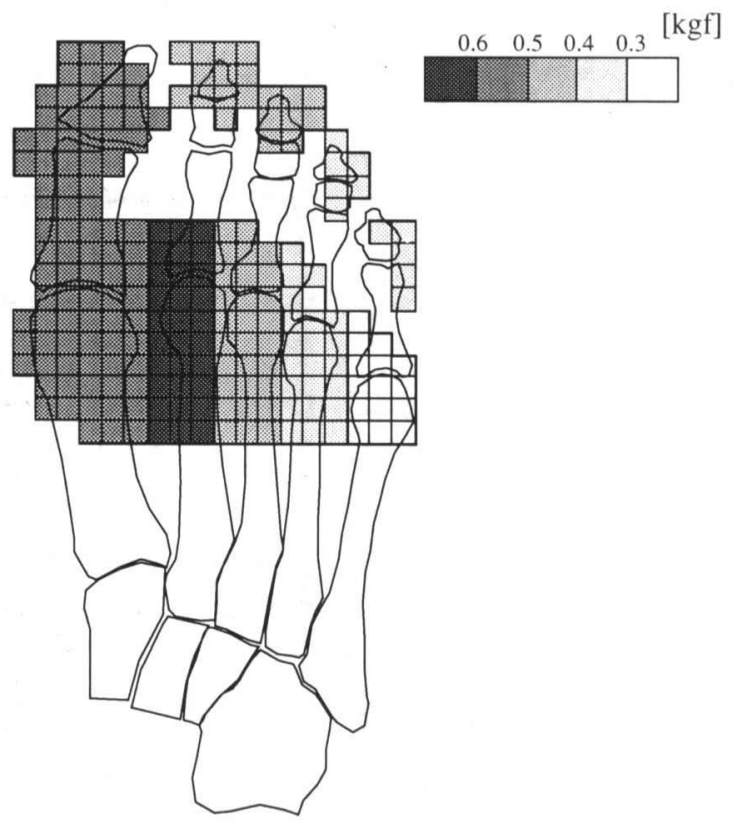

Fig.13 Planter load distribution measured by pressure sensers 
グ動作を原因とするものであり，第二趾におい て最大となり，第一趾，第三趾，第四趾，第五 趾の順に減少する.各意匠は分離独立しており, その変形状態は作用寸る荷重により異なる。 こ れは，ソール設計を行なう際には，本論文で提 案した解析手法に, Fig.13に示したような荷重分 布を適用しなければならないことを示唆するも のである。

\section{5 . 結言}

シューズ材料の粘弾性特性を考慮した数值モ デルを用いてグリップ性評価手法を開発し，実 験との比較によりその妥当性を検証した。本手 法を用いて評価を行なった結果，ドライな路面 においては，ミッドソールの変形を促進し，ア ウターソールの変形を抑制すると共に，境界面 に高剛性を有する第三層を介在させることによ ク，高いグリップ性をソールに付与しうること
が明らかとなった。ウェットな路面においては, ソール路面間の水膜に相当する界面相を適用し たモデルを新たに構築し,評価を行なった結果, 高グリップを有するソール構造がドライな路面 のそれとは異なることが明らかとなった。

\section{参 考 文 献}

1）小野英哲他，建築物の床のすべりおよびその評価方 法に関する研究, 日本建築学会大会学術講演集, (1980), pp.339-340.

2 ）吉岡 丹他，建築物の床のすべりに関する研究，日 本建築学会大会学術講演集, (1983), pp.267268.

3 ）西脇剛史, 計算工学講演会論文集, vol.3，(1998）, pp.303-306.

4) Tsuyoshi Nishiwaki, A new numerical modeling for laminated composities, Composite Structure, vol.32, (1995), pp.641-647. 